\title{
VIZUÁLNÍ SLAST A TĚLESNÁ ROZKOŠ JAKO PRVKY NAPÍNAVÉ SPEKTAKULÁRNÍ PODÍVANÉ. Modely hardcore erotiky $v$ italských populárních žánrech sedmdesátých a osmdesátých let
}

\author{
JAN ŠVÁBENICKÝ \\ Filmový historik
}

\begin{abstract}
Abstrakt: Studie se zabývá hardcore erotikou v populárních žánrech italské kinematografie v období sedmdesátých a osmdesátých let. Poukazuje na př́kladu různých filmů na obtížné aplikování pojmu pornografie na italský film a přiklání se k termínu hardcore erotika, který přesněji definuje míru intenzity v zobrazování sexu. Text zároveň zkoumá souvislosti mezi soft a hard erotikou v italských populárních žánrech v kontextu explicitních forem erotiky, které představují diskutabilní hranici mezi soft a hard prvky v napínavé podívané. Studie nahlíží na problematiku jako na sociokulturní fenomén, který se postupně vyvíjel od natáčení hardcore scén pro filmy určené pro běžná kina přímo až k produkci čistě hardcore erotických snímků pro dospělé publikum. Součástí analýzy je také pohled na praktiky a postupy zahraničních distribučních společností, které si od italských filmařu objednávaly dotáčky hardcore sekvencí k filmům různých populárních žánrů a softcore erotickým snímkům. Hard scény k některým italským filmům vznikaly z iniciativy distributorů v Itálii, ale také v zahraničí. Text na několika př́kladech prezentuje tvorbu režisérů rozmanitých populárních žánrů, kteří začali na přelomu sedmdesátých a osmdesátých let natáčet hardcore erotické filmy pro specializované projekce v nočních kinech i pro videodistribuci. U některých filmařu - nap̌r. Aristida Massaccesiho, který vystupoval pod pseudonymem Joe D'Amato - sloužily hardcore prvky k ozvláštnění napínavé podívané nebo tvưrci naopak používali rozmanité žánrové roviny k pojetí hardcore erotiky jako nového způsobu zobrazování sexu ve filmovém vyprávění. Text je obecně zaměřen i na významové spojitosti mezi žánrovými strukturami a hardcore erotikou.

Klíčová slova: hardcore erotika, softcore erotika, erotický film, populární žánry, italská kinematografie, filmová distribuce, filmový průmysl, hardcore sekvence, sexualita ve filmu, Aristide Massaccesi (Joe D'Amato)
\end{abstract}

Rozmanité formy erotiky jsou s italskou kinematografií úzce spojeny již od jejích němých počátků, přičemž mnohé snímky s touto tematikou se - podobně jako jiné žánry - nedochovaly. Kategorie žánrovosti je ve vztahu $k$ filmové erotice obecně diskutabilní, nebot erotika sama o sobě žánrem není, ale způsoby, jakými bývají tvůrci rozvíjeny různé tematické konvence a formální postupy, mohou být vodítkem k definování erotiky jako samostatného žánru. Obecně se nejčastěji setkáváme s termínem erotický film, ale ve skutečnosti se jedná o podívanou prolínající rozmanité žánrové roviny, kde je erotika zastoupena pouze jako téma nebo stylotvorný prvek. Chápání erotického filmu jako svébytné žánrové kategorie závisí na míře zastoupení erotiky ve vyprávěcí struktuře, kde se stává hlavním pilírem narativní konstrukce i stylistického pojetí jednotlivých filmů. S tímto aspektem se pojí i jiná problematická definiční vymezení nepřesně označovaná jako pornografický film, pornografie či ve zkratce porno. ${ }^{1}$ Jakkoliv mají všechny tyto pojmy i jejich další terminologické varianty pevné ukotvení v historii kultury i kinematografie, bývají - především ve vztahu k filmu

\footnotetext{
${ }^{1} \mathrm{~V}$ Itálii se tyto pojmy používají k definování hardcore erotiky ve filmu dodnes, ale stejně tak filmoví historici, publicisté a kritici používají i jiné terminologické alternativy jako hardcore erotika, hardcore film, hardcore erotický film apod. V období šedesátých až osmdesátých let byly za pornografické či obscénní často označovány i snímky s pouhými erotickými náznaky nebo scénami se soft erotikou.
} 
- velmi nejasné a obtížně použitelné. Samotnou otázkou zůstává hranice v zobrazování erotiky vybízející k charakterizování toho, co je či naopak není pornografie. ${ }^{2}$

Tento aspekt si můžeme ukázat na jednom obecném žánrovém příkladu bez vztahu ke konkrétnímu filmu. Například psychologické drama o citové nebo existenciální krizi v milostném vztahu dvou partnerů může během celého vyprávění zobrazit pouze jednu erotickou scénu, která je natočena velmi explicitním způsobem a detailně zobrazuje pohlavní znaky i tělesný styk. Tato skutečnost ještě nedělá film pornografickým, jakkoliv je zde erotika prezentována v tomto smyslu. Pojem pornografie je ve vztahu ke kinematografii obecně chápán ve smyslu, že hard erotika je hlavní a jedinou náplní podívané, přičemž u filmů v této studii představuje pouze jednu z linií napínavého vyprávění. Také z tohoto důvodu odmítám používat termín pornografie.

Rovněž snímky, jejichž dominantní obsahovou náplní jsou rozmanité formy erotiky, nepostrádají narativní linii, která je zastoupena bud’to vyprávěním s expozicí i zápletkou, nebo je příběh vyprávěn skrze vizuální zachycení erotiky, nahoty a lidského těla. V italské kinematografii byl v minulosti pojem pornografie filmovými kritiky a recenzenty nesprávně používán i k označení intelektuálních filmů, které se provokativním zpo̊sobem vyjadřovaly $\mathrm{k}$ sexu či zobrazovaly erotiku jako metaforu různých společenských mechanismů. Například snímkům Poslední tango v Pař́žzi (Ultimo tango a Parigi, 1972) Bernarda Bertolucciho, Velká žranice (La grande abbuffata, 1973) Marca Ferreriho nebo Salò aneb 120 dnů Sodomy (Salò o le 120 giornate di Sodoma, 1975) Piera Paola Pasoliniho ${ }^{3}$ byla v době jejich vzniku kritikou z etických pozic vytýkána morální zvrácenost a pornografické ztvárnění erotiky, přičemž s pornografií v jejím dnešním významu nemají vůbec nic společného. Nejednalo se o erotiku ve smyslu ukojení divákova libida, která představuje hlavní a jedinou náplň filmu, ale o erotiku jako metaforický symbol moci. Podobným způsobem byly nahlíženy také některé literární adaptace a výpravné kostýmní podívané situované do vzdálené minulosti jako Pasoliniho Dekameron (Il Decameron, 1970), Canterburské povídky (I racconti di Canterbury, 1971) a Kytice z Tisíce a jedné noci (Il fiorile delle mille e una notte, 1973). ${ }^{4} \mathrm{Již}$ tehdejší výklad pojmu pornografie byl nesprávný, nebot’ v západoevropské kinematografii byly distribučně zastoupeny americké snímky s explicitně otevřenou či přímo hard erotikou. Pro přesnější rozlišení pojetí erotiky v italské kinematografii budu ve studii používat terminologicky přijatelnější pojmy soft erotika a hard erotika nebo soft erotický či hard erotický film. Termín pornografie je ve vztahu k tematicky, formálně a žánrově mnohovrstevnaté povaze kinematografie obtížně použitelný, nebot' nerozlišuje hranice v zobrazování erotiky.

\section{Prvky hardcore erotiky např́íč italskými populárními žánry}

Italské populární žánry s hard erotickými prvky byly v Itálii od první poloviny sedmdesátých let jednou ze strategií producentů, distributorů a filmového průmys-

\footnotetext{
${ }^{2}$ Více o terminologickém vymezení soft a hard erotického filmu viz ŠVÁBENICKÝ, J. Vizuální slast mezi soft a hard erotikou. In Playboy, 2018, roč. 24, č. 8, s. 120 - 122.

${ }^{3}$ Více o uvedených filmech Piera Paola Pasoliniho viz VIANO, M. Pier Paolo Pasolini a jeho filmy. Praha : Václav Žák - Casablanca, 2017, s. 325 - 340.

${ }^{4}$ Více o uvedených Pasoliniho filmech viz tamtéž, s. 297 - 322.
} 
lu jak zatraktivnit domácí produkci na mezinárodním trhu. ${ }^{5} \mathrm{~V}$ některých případech měly jednotlivé snímky dvojí distribuční uvedení - v Itálii a zahraničí -, ale hard verze různých populárních žánrů se soft erotikou vznikaly zejména jako exportní produkce vyvážené do USA, západoevropských, jihoamerických a asijských zemí. Zatímco hard sekvence $\mathrm{v}$ některých italských filmech vznikaly přímo na zakázku ze zahraničí, $\mathrm{v}$ jiných př́ípadech volili tento postup italští producenti a distributoři, aby v rámci velké divácké a distribuční poptávky po erotice zajistili titulům širší a finančně úspěšnou distribuci. Podobně jako mnohé jiné populární žánry, nalezly i rozmanité formy erotiky v italských populárních žánrech největší odezvu v Západním Německu a Japonsku, kde tematika sexu a násilí odpovídala liberálnímu klimatu ve společnosti.

Obraz sexuality a erotiky - zejména v provokativním zobrazení v kontextu společenských, náboženských a etických konvencí - podléhal v Itálii cenzurním zásahům a italské publikum tak mělo možnost shlédnout málokterý film v jeho původní nesestř́hané podobě. Oproti období šedesátých let zasahovala cenzura zejména vůči explicitnímu znázornění sexuality s tvưrčím záměrem narušovat společenská tabu a provokovat publikum spojením sexu s doposud tabuizovanými tématy (rodina, náboženství, incest, sodomie). V šedesátých letech podléhaly cenzuře již pouhé vizuální náznaky sexuality nebo její prezentace $\mathrm{v}$ dialozích postav, přičemž byly mnohé italské snímky odsuzovány cenzurními komisemi jako obscénní podívaná narušující společenské mravy. Jednalo se o běžné narativní filmy rozmanitých žánrových poloh, zahrnující také komedie nebo literární adaptace. Jednou z příčin velké poptávky po erotice v italské kinematografii byly právě společensky provokativní snímky intelektuálních filmařů nahlížející na sex v rámci tradičních institucí jako církev a rodina.

Italský filmový historik a teoretik Giancarlo Grossini, používající terminologické označení porno, vztahuje tento pojem na obě oblasti erotického filmu: soft i hard erotiku. ${ }^{6}$ Poukazuje na skutečnost, že oba tyto okruhy kinematografie rozvíjejí erotiku jako podívanou využívající jako výrazového prostředku „obscénní jazyk “. ${ }^{7}$ Zatímco hard filmy jsou pro Grossiniho explicitním znázorněním erotiky, soft filmy pracují $\mathrm{s}$ intuitivním vyjádřením sexuálního aktu. S touto definicí, rozvinutou na počátku osmdesátých let, lze dnes souhlasit pouze do určité míry, nebơ vizuální hranice mezi soft a hard erotikou - včetně míry zastoupení obrazu sexuality v jednotlivých filmech - je velmi úzká. V kontextu italské kinematografie se používá také jiný termín, cinema a luci rosse (film v červených světlech) ${ }^{8}$, který zahrnuje široký záběr snímků s erotickou tematikou a jehož název vychází z kabaretních a striptýzových vystoupení v nočních klubech s červenými dekoracemi a reflektory.

Jedním z prvních impulsů k produkci filmů s erotickými náměty v italské kinematografii byly stylizované investigativní dokumenty, které se začaly natáčet na konci padesátých let a jež získaly definiční označení mondo film. Pojmenování vychází z tematické charakteristiky mnohých snímků, jež se natáčely v lokalitách celé-

${ }^{5}$ BRUNETTA, G. P. Il cinema italiano contemporaneo da "La dolce vita" a "Centochiodi“. Roma - Bari : Editori Laterza, 2007, s. $421-433$.

${ }^{6}$ GROSSINI, G. I 120 film di Sodoma. Analisi del cinema pornografico. Bari : Edizioni Dedalo, 1982, s. 64 - 65.

7 Tamtéž.

${ }^{8}$ Více informací o italském termínu cinema a luci rosse viz MANCINI, M. Interludi. Le grafie del porno II. In Fiction, 1979, roč. 2, č. 3 - 4, s. $101-108$. 
ho světa a měly povahu anketové a reportážní podívané. Produkce těchto filmů má i alternativní označení sexy film , nebot mnohé dokumentární snímky pojednávají o erotických klubech, striptýzových barech a nočních podnicích ve světových metropolích a nahlížejí na postavení sexu a erotiky v moderní industriální společnosti. Obraz ženské nahoty a fetišismu představovaný erotickým prádlem ovlivnil další vývoj erotické tematiky v populárních žánrech italské kinematografie šedesátých až osmdesátých let, kdy se soft a hard pojetí erotiky postupně stalo pevnou složkou filmového průmyslu.

Scény s hard erotikou se objevovaly v rozmanitých italských populárních žánrech již od první poloviny sedmdesátých let, kde se často nejednalo o tvưrčí záměr režisérů, ale iniciativu producentů a zejména distributorů s cílem uplatnit filmy v mezinárodní distribuci. K prvním takovým snímkům patřil La rossa dalla pelle che scotta (Červeň se žhnoucí kůží, 1972) Renza Russa, do něhož byly vloženy některé hard sekvence jako dodatečný materiál původně z jiného filmu. Tento produkční a distribuční postup se stal zavedenou strategií, jak promítat snímky určené pro běžná kina také jako specializované noční projekce pro dospělé publikum. ${ }^{10}$

V následujících letech se již rozvinula jiná metoda, kdy byly přímo natáčeny dvě verze filmu určené pro dvojí odlišné distribuční uvedení, což zajištovalo producentům a distributorům zisk z obou typů kin, jako byla běžná kina pro široké publikum a specializovaná noční kina pro diváky vyhledávající hard erotiku. Giallo all'italiana (detektivní film po italsku), do něhož se Russův snímek řadí, se ukázal být, zejména v druhé polovině sedmdesátých let, jedním z nejvíce adaptabilních populárních žánrů ohledně užití scén s explicitní a hardcore erotikou. Ojedinělým experimentem zůstal $\mathrm{v}$ tom to ohledu film Rivelazioni di uno psichiatra sul mondo perverso del sesso (Odhalení psychiatra v perverzním světě sexu, 1973) Renata Polselliho, který kombinuje stylizovanou dokumentární anketu s psychedelickým dramatem a odkazy na freudovskou psychoanalýzu. Hard erotické scény jsou v Polselliho snímku pevnou součástí narativní struktury a zobrazují erotiku jako akt společenské liberalizace i touhu po morálně zapovězených sexuálních experimentech. Jakkoliv už v těchto filmech má hard erotika libidinózní charakter, $\mathrm{k}$ jejímu upevnění docházelo až ve spojení s jinými žánry.

Italští producenti a distributoři nalézali nejefektivnější propojení soft a hard erotiky s populárními žánry, jejichž vyprávění bylo založené na mysteriózních, nadpřirozených, fantastických i exotických prvcích. Divácky úspěšné modely napínavé podívané italské kinematografie, které měly již dlouhodobější zavedený status v zahraničí, se staly pevnou součástí procesu tematické a formální recyklace v nový typ atraktivního vyprávění. Obraz násilí a krvavé efekty, které například v italských hororech doposud fungovaly $\mathrm{v}$ rámci gotických přiběhů o nadpřirozených bytostech, nabyly ve spojitosti se soft a hard erotikou nového ikonografického významu. ${ }^{11}$ Gotické horory Nuda per Satana (Nahá pro Satana, 1974) Luigi Batzelly, Malabimba (Zlé

\footnotetext{
${ }^{9}$ Podrobnější informace o termínu sexy film viz BRUSCHINI, A. - TENTORI, A. Nudi e crudeli. I mondo movies italiani. Milano : Bloodbuster, 2013, s. 21 - 41.

${ }^{10}$ Podrobnější informace o této produkční a distribuční strategii viz DELLA CASA, S. Splendor. Storia (incensueta) del cinema italiano. Bari : Editori Laterza, 2015, s. 94 - 98.

${ }^{11}$ Podrobnější analýza prolínání soft a hard erotiky v italském hororu viz CURTI, R. - LA SELVA, T. Sex and Violence. Percorsi nel cinema estremo. Torino : Lindau, 2003, s. 299 -302.
} 
děvčátko, 1979) Andrey Bianchiho nebo La bimba di Satana (Satanovo děvčátko, 1982) Maria Bianchiho byly natočeny ve dvou verzích: se soft a hard erotickými sekvencemi. Tvůrci a producenti tak prolínají fantaskní napínavou podívanou odehrávající se ve starobylých šlechtických usedlostech s provokací divákova libida.

Spojení sexu a násilí se v italské populární kinematografii etablovalo jako osvědčený recept pro široké publikum, které vyhledávalo žánry nejen jako zdroj napětí, ale také vizuálně atraktivních prvků. Erotika, která byla v italském hororu téměř vždy př́tomná - od pouhých náznaků až po rozmanité podoby soft sexu -, se zejména od druhé poloviny sedmdesátých let často objevovala v různých explicitních formách. Například snímek Noci hrũzy (Le notti del terrore, 1981) Andrey Bianchiho prolíná krvavý př́běh s explicitními erotickými scénami o skupině lidí izolovaných na venkovské usedlosti, která je v obležení živých mrtvých. ${ }^{12}$ Propojení strachu, napětí a libidinózních instinktů tak představovalo novou strategii italského filmového průmyslu, jak inovovat žánry a udržet zájem širokého publika.

Obtížně definovatelnou erotickou linku rozvíjí mnoho italských filmů sedmdesátých a osmdesátých let, kde je soft erotika ve své explicitní formě již náznakem hardcore, aniž by $\mathrm{k}$ zobrazení takových scén v průběhu vyprávění nakonec došlo. Na podobném principu erotické provokace vůči publiku rozvíjejí explicitní obraz sexuality také dobrodružná exotická dramata Orinoco, prigioniere del sesso (Orinoko, sexuální zajatkyně, 1979) a Femmine infernali (Pekelné ženy, 1980) Edoarda Mulargii, jejichž integrální verze určené pro mezinárodní distribuci již obsahují hardcore scény. ${ }^{13}$ Zatímco některé snímky využívali erotickou explicitnost pouze jako náznakovou provokaci divákova libida, jiné filmy konceptuálně navazovaly na tento postup hard erotikou. Touto produkční strategií tak tvůrci umožnili prezentovat jednotlivé snímky také jako hardcore podívanou. ${ }^{14}$

Adaptabilita hardcore erotiky na rozmanité formy populárních žánrů se ukázala jako nejosvědčenější bud'to u podívané zaměřené na napětí (horor, thriller, sci-fi) či přímo u filmů založených na softcore erotice. Z širokého spektra snímků uved’me př́klady jako exotické drama Il pavone nero (Černý páv, 1974) Osvalda Civiraniho, válečné drama z druhé světové války La svastica nel ventre (Svastika na břiše, 1976) Maria Caiana nebo sci-fi snímek La bestia nello spazio (Bestie ve vesmíru, 1980) Alfonsa Brescii, u nichž byly na objednávku zahraniční distribuce nebo z iniciativy italských producentů dotáčeny k soft erotickým scénám také kratší hardcore vsuvky. Tyto produkční a distribuční praktiky vznikaly - podobně jako u výše uvedených př́íladů - bez vědomí režisérů a scenáristů, v jejichž původním pojetí obsahovaly filmy pouze soft erotické scény. ${ }^{15}$ Poptávka po hardcore scénách dokládá, že byly ve spojení s populárními žánry divácky atraktivní podívanou a nabourávaly prvotní žánrové hranice.

Zahraniční distributoři si pro projekce ve specializovaných nočních kinech pro dospělé publikum vybírali také jiné filmy populárních žánrů italské kinematogra-

\footnotetext{
${ }^{12}$ Podrobnější analýza problematiky kombinování erotického filmu a hororu v italské kinematografii viz tamtéž.

${ }^{13}$ Více informací o zmíněných filmech Edoarda Mulargii viz DI MARINO, Stefano. ....in carcere. La „doppietta“ di Mulargia. In DI MARINO, S. - ARTALE, C. Tutte dentro. Il cinema della segregazione femminile. Milano : Bloodbuster, 2013, s. 87 - 89.

${ }^{14}$ Více o produkčních strategiích těchto filmů viz DELLA CASA, S. Splendor. Prima della rivoluzione, s. $94-98$.

${ }^{15}$ Více o produkčních a distribučních praktikách těchto filmů viz tamtéž.
} 
fie, kde se bud'to jednalo o vybízející tematickou návaznost na softcore erotiku, nebo o vizuální experimenty. Patř́ mezi ně např́iklad detektivky La rosa dalla pelle che scotta Renza Russa a Prostituzione (Prostituce, 1974) Rina Di Silvestra, thriller Carnalità (Tělesnost, 1974) Afreda Rizza nebo komedie La professoressa di lingue (Profesorka jazyků, 1976) Demofila Fidaniho. V mnoha př́ípadech se vložené hardcore sekvence vyznačují neorganickým propojením s formálním pojetím filmových záběrů, nebot byly natočeny na zcela odlišný filmový materiál, nebo byly použity z jiných (hardcore) filmů. ${ }^{16}$ Stejně jako pro širokoúhlé kinoprojekce se tyto rozšířené verze uplatnily během osmdesátých let také ve videodistribuci, kde nalezly ještě širší divácký zájem.

K ojedinělým experimentům na poli hardcore podívané patří v kontextu sedmdesátých let také populární žánr western all'italiana (western po italsku), kde rovněž došlo $\mathrm{k}$ úpravě již jiného natočeného filmu. $\mathrm{V}$ př́padě westernu Lo ammazzò come cane... ma lui rideva ancora (Zabil jsem ho jako psa... ale on se ještě smál, 1972) zvolil režisér Angela Pannacciò odlišný postup. Použil některé záběry ze svého filmu, které společně s nově natočenými hardcore erotickými scénami sestř́hal v nový snímek Porno erotico western (Porno erotický western, 1979).${ }^{17}$ Kromě dotočeného hard materiálu Pannacciò změnil také žánrovou polohu westernu z dramatické podívané na komediální pojetí. Recyklací původní žánrové ikonografie snímku na hard erotiku vytvořil režisér z westernu předmět fetišistické slasti.

\section{Od explicitních forem erotiky $\mathrm{k}$ produkci hardcore filmů}

Vedle snímků, k nimž byly na objednávku zahraničních distributorů dotáčeny scény s hardcore erotikou a jejichž původní pojetí bylo z pohledu filmových tvưrců zcela odlišné, vznikaly také filmy př́mo založené na dvojím distribučním využití. Právě tyto snímky zahájily v Itálii natáčení hardcore erotiky ve smyslu sériové populární produkce filmového průmyslu. Patřily $\mathrm{k}$ nim především některé tituly z erotického cyklu o černé Emanuelle ${ }^{18}$, u nichž byly přímo během natáčení realizovány také hardcore sekvence, které byly vkládány do integrálních verzí pro mezinárodní distribuci ve specializovaných nočních kinech. Nejednalo se tedy o dodatečné natáčení hard erotiky k již realizovaným snímkům, jak tomu bylo u výše uvedených filmů. Snímek Emanuelle nera (Černá Emanuella, 1975) Adalberta Albertiniho a filmy Emanuelle in America (Emanuella v Americe, 1976) či Emanuelle, perché violenza alle donne? (Emanuello, proč násilí na ženách?, 1977) Aristida Massaccesiho obsahují hardcore scény natáčené s dvojníky herců vystupujících pouze v sekvencích se softcore erotikou. Režisér Massaccesi, známý v oblasti erotizace populárních žánrů především pod tvůrčím pseudonymem Joe $\mathrm{D}^{\prime} \mathrm{Amato}^{19}{ }^{19}$, později často uplatňoval tento strategický postup i ve svých dalších filmech s rozmanitými ikonografickými a lokalizačními

\footnotetext{
${ }^{16}$ Více o produkčních a distribučních praktikách těchto filmů viz tamtéž.

${ }^{17}$ Více informací o tomto filmu viz BRUSCHINI, A. Lo ammazzò come un cane... ma lui rideva ancora. In PISELLI, S. - MORROCCHI, R. Western all'italiana. The Wild, the Sadist and the Outsiders. Firenze : Glittering Images, 2001, s. 138 - 139.

${ }^{18}$ Podrobnější analýza populárního fenoménu filmů o černé Emanuelle viz ŠVÁBENICKÝ, J. Ve spodním prádle na cestě kolem světa. Italská populární erotická série o černé Emanuelle. In Cinepur, 2014, roč. 21, č. 91 , s. $31-35$.

${ }^{19}$ Více informací o soft a hard erotické tvorbě režiséra Aristida Massaccesiho viz LUPI, G. Erotismo, orrore e pornografia secondo Joe D'Amato. Roma : Mondo ignoto - Profondo Rosso, 2004, s. 113 - 117.
} 
charakteristikami příznačnými pro konkrétní žánrové polohy. Jako nejefektivnější vizuální spojení s hard erotikou se ukázalo být v Massaccesiho filmech exotické a tropické prostředí, kde docházelo také k etnickým kombinacím sexuálních partnerů v hardcore sekvencích. ${ }^{20}$ Tímto tvưrčím postupem vytvářel Massaccesi pro publikum vizuálně atraktivní obraz sexu, který nebyl v italských populárních žánrech s hard erotikou př́liš zavedeným.

Propojení exotických atributů s hardcore erotikou reprezentuje v Massaccesiho tvorbě především série snímků realizovaných v exteriérech Dominikánské republiky. Zatímco Sesso nero (Černý sex, 1978), Orgasmo nero (Černý orgasmus, 1980) a Porno Esotic Love (1980) ${ }^{21}$ rozvíjejí zejména kombinaci dramatu s hard erotikou, v jiných snímcích se režisér zaměřil na populární žánry vyhledávané publikem i bez vztahu k sexualitě. Právě v těchto př́ípadech nejvíce docházelo k ikonografickému ozvláštnění hard erotiky jejím zasazením do vizuálních schémat a žánrových konvencí napínavé podívané. Patří mezi ně thriller Hard Sensation (1980) a horory Le notti erotiche dei morti viventi (Erotické noci živých mrtvých, 1980) a Porno Holocaust (1981), kde tvůrce propojením submisivního sexu s násilím a nadpřirozenými prvky navozuje dojem ikonografické fetišizace erotiky. Prolínání napínavých dramatických situací s rozmanitými formami hard erotiky nabízí divákovi dvě roviny vizuální slasti: čistě kinematografickou spojenou s žánrovými atributy a erotickou zaměřenou na libidinózní touhy recipienta.

Podobnou tvůrčí strategii v souvislosti s modifikací žánrových prvků pro dospělé publikum uplatňoval Massaccesi i ve filmech odehrávajících se mimo exotické prostředí, jako jsou historická kostýmní dramata Immagini di un convento (Výjevy z kláštera, 1979), Caligola, la storia mai raccontata (Caligula, nikdy nevyprávěný př́iběh, 1982) nebo thriller Il porno shop della settima strada (Porno shop na sedmé ulici, 1979). Kostýmy, výprava i násilí jako konstrukční prvek napětí zde posouvají hardcore erotickou podívanou do nové významové polohy s cílem konkurovat snímkům z jiných západoevropských kinematografií v mezinárodní distribuci.

Massaccesi, který byl od druhé poloviny sedmdesátých let také producentem svých filmů v rámci vlastní produkční společnosti Filmirage i u jiných firem (Kristal Film, Cinema 80, M.A.D. Film), natáčel některé snímky na základě využití kulis, kostýmů i lokalizací z předchozích produkcí. Tento úsporný systém mu umožňoval sériové natáčení filmů, v nichž často převažovaly nad narativní linií hardcore scény. Vedle historických hardcore filmů z antického Ríma jako Messalina, orgasmo imperiale (Mesalina, imperiální orgasmus, 1983) a Una vergine per l'impero Romano (Panna pro Římské impérium, 1983) režíroval především komorní snímky situované do moderních městských vil nebo venkovských usedlostí. Přestože mají i tyto filmy vyprávěcí strukturu a rozvíjejí témata vztahových krizí nebo liberálních postojů $\mathrm{k}$ sexu, je zde hlavní zájem centralizován na orální sex a koitus v hardcore pojetí erotiky. ${ }^{22}$ Massaccesi volil rozmanité názvy jednotlivých filmů, jimiž vytvářel tematické cykly a kterými apeloval na publikum pojmy probouzejícími sexuální libido. Nejpočetnější skupinu filmů tvoří snímky reprezentující ve svých názvech sexuální praktiky či ero-

\footnotetext{
${ }^{20}$ Více o tematice sof a hard erotických filmů Aristida Massaccesiho viz tamtéž.

${ }^{21}$ Více o žánrových kombinacích a o problematice pojetí erotiky v Massaccesiho filmech viz TENTORI, A. Voglia di guardare. L'eros nel cinema di Joe D'Amato. Milano : Bloodbuster, 2014, s. 93 - 95.

${ }^{22}$ Více o pojetí hard erotiky v Massaccesiho tvorbě viz tamtéž.
} 
tické výzvy: Bocca golosa (Mlsná ústa, 1981), Sesso acerbo (Nezralý sex, 1981), Voglia di sesso (Sexuální touha, 1981), La voglia (Touha, 1981), Stretta e bagnata (Sevřená a vlhká, 1982), Delizie erotiche (Erotické rozkoše, 1982), Orgasmo infernale (Pekelný orgasmus, 1983). ${ }^{23}$ Krátké a výstižné slovní formulace a spojení obvykle představovaly, společně s eroticky provokativními motivy grafik filmových plakátů, nejefektivnější propagaci snímků u diváka vyhledávajícího hard erotickou podívanou. Dlouhé názvy filmů používané italskými producenty a distributory i u jiných populárních žánrů - především u westernů a komedií - nebyly v tomto případě z hlediska lepší propagační komunikace s divákem praktikovány.

Hardcore erotické snímky natáčeli v první polovině osmdesátých let také filmaři, kteří byli dříve angažováni producenty k tvorbě rozmanitých populárních žánrů zahrnujících komedie, melodramata, westerny, dobrodružné filmy apod. V titulcích mnohých hard filmů figurují režiséři Roberto Bianchi Montero, Marino Girolami, Sergio Bergonzelli, Renato Polselli, Cesare Canevari, Roberto Mauri, Andrea Bianchi, Mario Siciliano, Angelo Pannacciò, Roberto Girometti nebo Mario Bianchi. Intenzita působnosti těchto filmařů $\mathrm{v}$ produkci hard erotiky byla různá a ve většině případi̊ úzce souvisela s aktuální poptávkou publika, producentů a distributorů. Mnohdy se jednalo pouze o alimentární snímky natočené výhradně na zakázku pro domácí a zahraniční filmový trh. U některých režisérů se jedná pouze o ojedinělé projekty, po nichž již nenásledovala tvorba dalších hardcore snímků. Například u filmů Sesso profondo (Hluboký sex, 1980) Marina Girolamiho, Le porno killers (Porno zabíječi, 1980) Roberta Mauriho, Delitto carnale (Tělesný zločin, 1982) Cesara Canevariho a La doppia bocca di Erika (Dvojí ústa Eriky, 1983) Sergia Bergonzelliho ${ }^{24}$ se jedná o jediné exkurze režisérů do oblasti hardcore erotiky, přičemž v některých případech existují dvě verze filmů (soft a hard) pro dvojí distribuční využití. ${ }^{25}$ Filmový průmysl usilující o tvorbu profesionálně pojatých hardcore snímků natočených postupy známými z jiných populárních žánrů italské kinematografie angažoval tyto i jiné tvưrce, aby vytvořil Z hard erotiky divácky žádaný a distribučně konkurenční artikl. Z tohoto důvodu producenti, scenáristé i režiséři často inklinovali k ikonografickým charakteristikám a žánrovým atributům jiných modelů napínavé podívané, v rámci kterých byla hard erotika novým vizuálním prvkem.

Někteří jiní režiséři, známí z tvorby neeroticky pojatých populárních žánrů, se zejména $\mathrm{v}$ první polovině osmdesátých let zaměřovali na natáčení hardcore erotických filmů pravidelně, přičemž využívali formálních postupů a žánrových konvencí běžné narativní kinematografie. Zatímco snímky Albergo a ore (Hodinový hotel, 1981) a L'amore e la bestia (Láska a bestie, 1986) Roberta Bianchi Montera nebo Giochi carnali (Tělesné hry, 1983) a Morbosamente vostra (1985) Andrey Bianchiho představují ve tvorbě obou režisérů hardcore erotiku jako občasné žánrové experimentování v oblasti zakázkové produkce pro dospělé publikum, u jiných tvůrců se jedná přímo

\footnotetext{
${ }^{23}$ Více o strategickém pojetí názvů Massaccesiho snímků viz tamtéž.

${ }^{24}$ Zahraniční distribuční verze některých filmů Sergia Bergonzelliho z období sedmdesátých a osmdesátých let obsahují hardcore sekvence k využití snímků ke speciálním projekcím i distribuci na videokazetách. Jedná se např́klad o tituly Cristiana, studentessa degli scandali (Cristiana, studentka skandálů, 1971), La cognatina (Švagrová, 1975), La sposina (Mladá nevěsta, 1976), La trombata: Quattro ladroni a caccia di milioni (Přepadení: Čtyři zloději na lovu miliónů) nebo Daniela mini-slip (Daniela, mini kalhotky, 1980).

${ }^{25}$ Více o dvojím distribučním využití italských erotických snímků viz CURTI, R. - LA SELVA, T. Sex and Violence. Percorsi nel cinema estremo, s. 299 - 302.
} 
o sériovou tvorbu variující hard sex na pozadí širokého žánrového rozpětí od komediální a dramatické roviny až $\mathrm{k}$ hororu. ${ }^{26}$ Tento model nalezneme např́klad ve filmech Maria Siciliana, který v šedesátých a sedmdesátých letech režíroval především akční, válečné a dobrodružné snímky. Spektakulární a výpravný charakter Sicilianových filmů s důrazem na epický rozměr vyprávění režisér nahradil komorními př́běhy s hard erotickými scénami. Některé tituly z jeho tvorby jako Erotic Family (Erotická rodina, 1980), Porno lui, erotica lei (Porno on, erotická ona, 1981), La zia svedese (Švédská teta, 1981), Sesso allegro (Veselý sex, 1981), Carnalità morbosa (Morbidní tělesnost, 1982), Orgasmo esotico (Exotický orgasmus, 1982), Orgasmo non-stop (Non stop orgasmus, 1982) využívaly v žánrových konstrukcích i distribuční propagaci podobné strategické postupy jako výše zmíněné filmy Aristida Massaccesiho. Apelační pojmy jako sex, erotika, porno či orgasmus se staly v rámci mnohých produkčních společností klíčovými komunikačními termíny mezi filmovými tvůrci a publikem vyhledávajícím hard erotiku k vizuálnímu uspokojení libida.

Zatímco někteří režiséři zůstali u natáčení hardcore erotických filmů pouze v období osmdesátých let, kdy stoupala divácká a distribuční poptávka po tomto modelu podívané, jiní tvůrci pokračovali v natáčení hard erotiky i v devadesátých letech a zabývali se výhradně již pouze touto produkcí ${ }^{27}$ Vedle zmíněného Aristida Massaccesiho patřili k těmto režisérům například Mario Bianchi a Franco Lo Cascio, kteří rovněž začínali tvorbou v narativní kinematografii a natáčeli různé populární žánry. Snímky Vieni, vieni da me, amore mio (Pojd', pojd’ ke mně, má lásko, 1983), Marina... miele selvaggio (Marina... divoký med, 1984), Marina, i desideri di una nobildonna (Marina, touhy jedné šlechtičny, 1986) nebo Marina, un vulcano di piacere (Marina, vulkán potěšení, 1987) Maria Bianchiho jsou natočeny videotechnikou pro rozvíjející se videodistribuci, kde představovala hard erotika jeden z hlavních žánrových artikli̊. Podobně jako u Bianchiho, i ve tvorbě Franca Lo Cascia lze v produkci hard erotických filmů vysledovat technologickou proměnu filmového formátu od širokoúhlého obrazu příznačného pro narativní kinematografii až po videotechniku určenou $\mathrm{k}$ distribuci filmů na videokazetách. Lo Casciovy snímky Sesso allo specchio (Sex v zrcadle, 1981), Nido d'amore (Hnízdo lásky, 1984), La chiave del piacere (Klíč k potěšení, 1984), Le due... bocche di Marina (Dvě... ústa Mariny, 1985) či Marina, una moglie così perbene (Marina, manželka tak úctyhodná, 1986) dokládají na příkladu tvorby režiséra vývoj filmové technologie ve vztahu k hard erotické podívané a tím také postupnou proměnu typologie její distribuce. Přestože byly mnohé tyto snímky uváděny také na VHS trhu v Itálii, byly natáčeny především jako exportní zboží pro mezinárodní videodistribuci ${ }^{28}$ a zaměřovaly se na uspokojování divákova libida prostřednictvím tematických inovací a vizuálních extrémů.

V rámci hard erotiky jako populární podívané pro široké publikum vznikaly také vizuální experimenty využívající avantgardní postupy a rozbíjení logické návaznosti jednotlivých scén k provokaci publika zvyklého na lineárně se rozvíjející erotickou podívanou. Hranice mezi tradičním a atypickým pojetím hardcore se objevuje ve filmech Sì... lo voglio! (Ano... chci to!, 1980), Luce rossa (Červené světlo, 1981), Erotico 2000 (Erotika 2000, 1982) a Fantasia erotica in concerto (Erotická fantazie na koncertě,

${ }^{26}$ Více o problematice žánrového experimentování v italských soft a hard erotických filmů viz DELLA CASA, S. Sex and Violence. Percorsi nel cinema estremo, s. $94-98$.

${ }^{27}$ Více o produkci a natáčení hard erotických filmů v italské populární kinematografii viz tamtéž.

${ }^{28}$ Více o italské a mezinárodní distribuci italských hard erotických snímků viz tamtéž. 
1985) Angela Pannaccia, kde se prolíná lineární narativní styl s rušivými vizuálními prvky. Režisér Renato Polselli pojímá hard erotiku ve filmech Quando l'amore è l'oscenità (Když láska je obscénnost, 1980), Teresa, altri desideri (Tereza, jiné touhy, 1983), Marina e la sua bestia (Marina a její bestie, 1984) a Bocca bianca, bocca nera (Bílá ústa, černá ústa, 1986) jako vizuální extrémy, kterými zamýšlí šokovat diváka jejím neobvyklým zobrazením a sklony k anomáliím. Konkrétně Pannacciovy a Polselliho snímky dokládají, že se italský filmový průmysl pokoušel ozvláštňovat hard erotiku atypickými prvky i vizuálním ztvárněním, aby nabídl publiku nový typ podívané spojený s provokováním divákova libida. Režiséři často spojovali hard erotiku s perverzními a fetišistickými extrémy, které nabízely publiku vizuální slast s cílem vyvolat provokaci v rámci zavedených společenských konvencí (náboženská morálka, obraz měštáctví). K čistě avantgardnímu pojetí hard erotiky inklinuje režisér Alberto Cavallone, který dříve využíval ve svých filmech avantgardu jako prostředek k rozbíjení lineárně se rozvíjejícího vyprávění. Konkrétně ve snímcích Il nano erotico (Erotický skřítek, 1981), Pat, una donna particolare (Pat, zvláštní žena, 1982) a ...e il terzo gode (...a třetí se těší, 1982) Cavallone využívá hardcore erotiku jako prvek avantgardního experimentování s rozmanitými žánrovými rovinami (např. atypické střihové postupy, narušování lineárně se odvíjející dějové kauzality, snové prvky rozbíjející logiku jednotlivých situací apod.), kde představuje sex ozvláštňující složku anomálních a extrémních dějových situací.

\section{Několik poznámek závěrem}

Postavení soft a hard erotiky v italské populární kinematografii sedmdesátých a osmdesátých let je natolik specifické, že je obtížné vnímat tento fenomén ve významových intencích diskutabilního pojmu pornografie, v jakém bývá nejčastěji chápán a používán. Explicitní a hard erotické scény v rozmanitých populárních žánrech fungovaly v tomto období spíše jako ozvláštnění ikonografických prvků a vytvoření alternativní podívané pro dospělé publikum, než k pouhému uspokojení divákova libida. Mnohé snímky se vyznačují pevnou narativní strukturou a důrazem na rozpoznávací vizuální charakteristiky příznačné pro rozmanité žánrové roviny napínavého vyprávění. Např́klad filmy Le segrete esperienze di Luca e Fanny (Tajné zkušenosti Lucy a Fanny, 1980) a Professione: P... attrice (Povolání: P... herečka, 1982) Roberta Giromettiho rozvíjejí žánr dramatu v prostředí italské zámožné rodiny i filmového průmyslu zaměřujícího se na hard erotické filmy. V případě druhého zmíněného titulu se jedná o intertextový obraz sebereflexe tvorby snímků s hard erotikou. Produkce čistě hard erotických snímků založených pouze na uspokojování sexuálního chtíče publika byla pro italskou kinematografii charakteristická zejména od druhé poloviny osmdesátých let ${ }^{29}$, kdy byly mnohé filmy natáčeny videotechnikou a byly určeny zejména pro italskou i zahraniční videodistribuci. ${ }^{30}$ Tyto tituly představovaly v osmdesátých

\footnotetext{
${ }^{29}$ Vzhledem $\mathrm{k}$ různé míře využívání prvků hardcore erotiky v italských populárních žánrech nelze určit, který hard erotický film byl v italské kinematografii natočen jako první. Někteří filmoví kritici a historici pokládají za první hard snímek La parte più appetitosa del maschio (Nejpřitažlivější část samce, 1979) Lorenza Magnolii. I v tomto př́padě se ve skutečnosti jedná o erotický film s hardcore sekvencemi.

${ }^{30}$ Více o produkci a distribuci italských soft a hard erotických filmů viz DELLA CASA, S. Splendor. Storia (incensueta) del cinema italiano, s. $94-98$.
} 
a především devadesátých letech exportní artikl nabízený produkčními společnostmi mezinárodní distribuční síti videopůjčoven, kde nalezly svou klientelu napříč různými věkovými i sociálními kategoriemi diváků. Natáčení hardcore erotických filmů v Itálii vyplynulo z rostoucí distribuční a divácké poptávky po tomto modelu podívané na mezinárodním trhu, přičemž mnozí tvůrci známí z tvorby různých populárních žánrů působili $\mathrm{v}$ této oblasti převážně $\mathrm{z}$ finančních důvodů a vystupovali pod anglickými pseudonymy.

\section{VISUAL PLEASURE AND BODY DELIGHT AS ELEMENTS OF THRILLING SPECTACULAR CINEMA. Models of Hardcore Erotica in Italian Popular Genres of 70's and 80's}

\section{Jan ŠVÁBENICKÝ}

This study deals with hardcore erotica in popular genres of Italian cinema in the period of the 70's and 80's. Pointing to the example of various movies on the difficult application of the term pornography in Italian cinema and leans toward the concept of hardcore erotica that accurately defines the measure of intensity in the imaging of sex. The text simultaneously examines connections between soft and hard erotica in Italian popular genres, in the context of explicit forms of erotica that present questionable borders between soft and hard elements in the thrilling spectacle. The study perceives the problematics as a socio-cultural phenomenon which has gradually developed from the filming of hardcore scenes for movies designed for common cinemas, directly to production of purely hardcore erotic movies for the adult audience. Part of the analysis is also a view on practices and procedures of foreign distribution companies that ordered special material from Italian filmmakers, with hardcore sequences for movies of various popular genres and for soft core erotic movies. Hard scenes for some Italian movies were created from the initiative of distributors directly abroad. The text also presents several examples showing the creation of directors of various popular genres, who began filming hardcore erotic movies at the turn of the 70's and 80's for special screenings in night cinemas and for video distribution. Some directors - for example Aristide Massaccesi who used the pseudonym Joe D'Amato - served hardcore elements to make a special genre style of thrilling spectacle. Massaccesi on the contrary also used various genre levels to create a concept hardcore erotica as a new form of imaging of sex on the screen. This text is generally focused on semantic connections between genre structures and hardcore erotica.

\section{LITERATURA}

BRUNETTA, Gian Piero. Il cinema italiano contemporaneo da "La dolce vita " a "Centochiodi“. Roma - Bari : Editori Laterza, 2007, 827 s. ISBN 978-88-420-83740.

BRUSCHINI, Antonio. Lo ammazzò come un cane... ma lui rideva ancora. In PISELLI, Stefano MORROCCHI, Riccardo (a cura di). Western all 'italiana. The Wild, the Sadist and the Outsiders. Firenze : Glittering Images, 2001, s. 138 - 139. ISBN 88-8275-044-2. 
BRUSCHINI, Antonio - TENTORI, Antonio. Nudi e crudeli. I mondo movies italiani. Milano : Bloodbuster, 2013, 192 s. ISBN 978-88-902087-6-8.

CURTI, Roberto - LA SELVA, Tommaso. Sex and Violence. Percorsi nel cinema estremo. Torino : Lindau, 2003, 395 s. ISBN 88-7180-468-6.

DELLA CASA, Stefano. Splendor. Storia (incensueta) del cinema italiano. Bari : Editori Laterza, 2015, 131 s. ISBN 978-88-581-1993-8.

DI MARINO, Stefano. ...in carcere. La „doppietta“ di Mulargia. In DI MARINO, Stefano ARTALE, Corrado. Tutte dentro. Il cinema della segregazione femminile. Milano : Bloodbuster, 2013, s. 87 - 89. ISBN 978-88-902-087-8-2.

GROSSINI, Giancarlo. I 120 film di Sodoma. Analisi del cinema pornografico. Bari : Edizioni Dedalo, $1982,189 \mathrm{~s}$.

LUPI, Gordiano. Erotismo, orrore e pornografia secondo Joe D'Amato. Roma : Mondo ignoto - Profondo Rosso, 2004, 263 s. ISBN 88-89084-49-9.

MANCINI, Michele. Interludi. Le grafie del porno II. In Fiction, 1979, roč. 2, č. 3 - 4, s. $101-108$.

ŠVÁBENICKÝ, Jan. Ve spodním prádle na cestě kolem světa. Italská populární erotická série o černé Emanuelle. In Cinepur, 2014, roč. 21, č. 91, s. 31 - 35. ISSN 1213-516X.

ŠVÁBENICKÝ, Jan. Vizuální slast mezi soft a hard erotikou. In Playboy, 2018, roč. 24, č. 8, s. 120 - 122. ISSN 0862-9374.

TENTORI, Antonio. Voglia di guardare. L'eros nel cinema di Joe D'Amato. Milano : Bloodbuster, 2014, 160 s. ISBN 978-88-908986-1-7.

VIANO, Maurizio. Pier Paolo Pasolini a jeho filmy. Praha : Václav Žák - Casablanca, 2017, 408 s. ISBN 978-8087292-40-2.

Jan Švábenický

e-mail: jan.svabenicky@gmail.com 